$12-2018$

\title{
Justice for Genocide in Cambodia - The Case for the Prosecution
}

William Smith

Extraordinary Chambers of the Courts of Cambodia

Follow this and additional works at: https://digitalcommons.usf.edu/gsp

\section{Recommended Citation}

Smith, William (2018) "Justice for Genocide in Cambodia - The Case for the Prosecution," Genocide Studies and Prevention: An International Journal: Vol. 12: Iss. 3: 20-39.

DOI:

https://doi.org/10.5038/1911-9933.12.3.1658

Available at: https://digitalcommons.usf.edu/gsp/vol12/iss3/7

This Conference Proceeding is brought to you for free and open access by the Open Access Journals at Digital Commons @ University of South Florida. It has been accepted for inclusion in Genocide Studies and Prevention: An International Journal by an authorized editor of Digital Commons @ University of South Florida. For more information, please contact digitalcommons@usf.edu. 


\section{Justice for Genocide in Cambodia - The Case for the Prosecution}

\section{Acknowledgements}

This address was prepared with the assistance of Caroline Delava, Martin Hardy and Andreana Paz, legal interns in the Office of the Co-Prosecutor. The opinions in this address are those of the author solely and reflect the concepts and essence of the address delivered at the Conference. 


\title{
Justice for Genocide in Cambodia - The Case for the Prosecution
}

\author{
William Smith \\ Extraordinary Chambers of the Courts of Cambodia \\ Phnom Penh, Cambodia
}

The Importance of Contemporaneous Documents and Academic Activism*

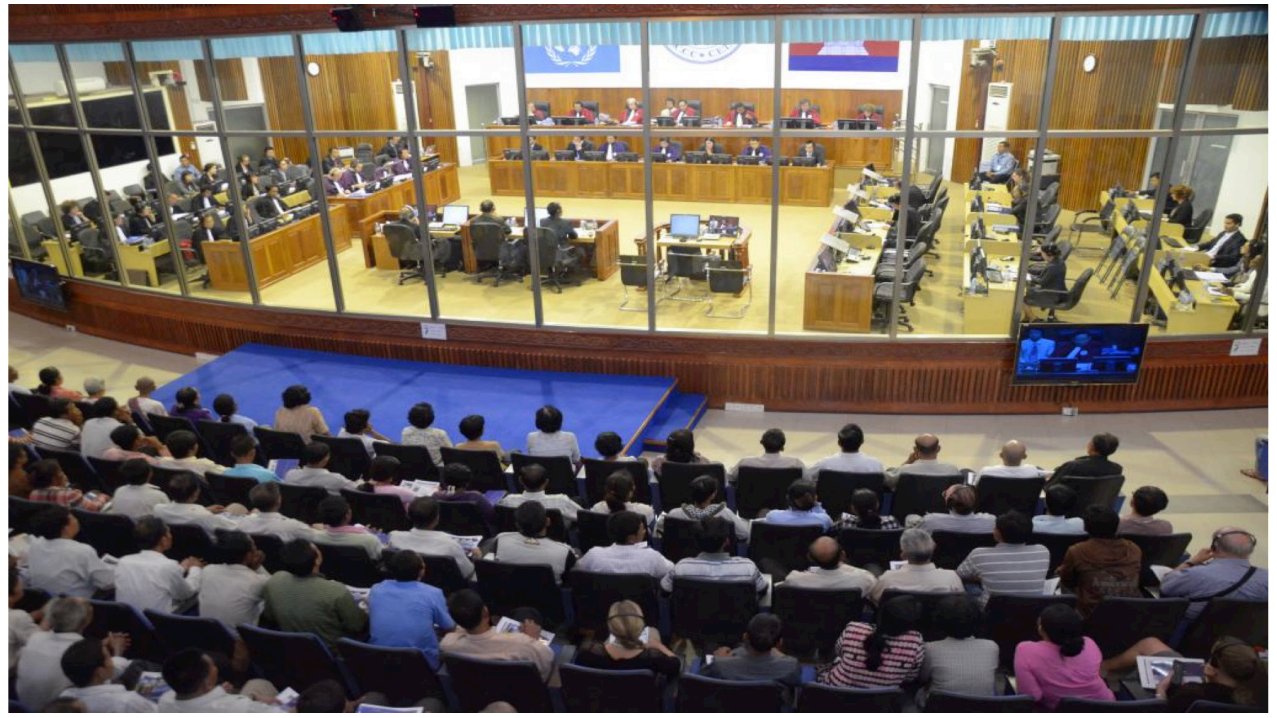

Figure 1. ECCC Case 002-01 trial in session.

Achieving justice for the genocide, crimes against humanity, and war crimes alleged to have occurred in Cambodia during the Democratic Kampuchea (DK) period has not been simple. In 2006, more than 25 years after the Communist Party of Kampuchea (CPK or Khmer Rouge) was ousted from power in Cambodia, ending its barbaric rule, the Extraordinary Chambers in the Courts of Cambodia (ECCC) began its investigations. Its mandate was to investigate the senior leaders and those most responsible for the crimes that occurred under the CPK. Critically, prior to the ECCC investigations, significant investigative, archival and analytical work had been carried out on the Khmer Rouge crimes by independent academics, researchers, journalists, investigators and analysts working with and independently from non-government organizations (NGOs) tasked with the same goal. Combined, these individuals and organizations have ensured that thousands of highly probative documents produced by the CPK were preserved, early interviews with victims, witnesses and suspects were recorded and painstaking analysis of the evidence discovered was undertaken. This pre-ECCC work has proved invaluable, assisting the investigators and parties in their investigation and presentation of cases, and the Chambers in their final judgments.

Today, I will highlight examples of some of this evidence that was collected prior to the operation of the ECCC, to illustrate the importance of this substantial research and analysis on the CPK documentation and the conduct of early interviews with suspects, witnesses and victims in assisting in proving the prosecution cases at the ECCC.

First, I would like to put the prosecution cases in the broader factual context on which the specific allegations against the accused at the ECCC have been made. Between 1975 and 1979, some of the worst crimes in history were committed in DK against millions of Cambodians, when the CPK took power after winning a five-year bloody war against the Khmer Republic government forces. Well before coming to power, and on gaining power, the CPK leadership sought to radically and rapidly transform Cambodian society from a capitalist feudal economy to an extreme communist agrarian society. In the three years, eight months and twenty days that the CPK was in power, it is estimated that at least 1.7 million people were killed through execution, overwork, starvation, malnutrition, disease, sickness and lack of medical care. Half of these deaths are estimated to

* William Smith is the International Deputy Co-Prosecutor in the Extraordinary Chambers of the Courts of Cambodia. 
have occurred as a result of executions, with the other half as a result of the inhumane conditions imposed upon Cambodians.

This radical vision was implemented through a number of CPK policies, beginning with the forcible transfer of the population of Phnom Penh and other towns to the countryside where people were forced to work under inhumane conditions on agricultural and infrastructure projects. These projects were aimed at rapidly increasing Cambodia's production and create self-reliance. As part of this policy the CPK aimed to increase the size of the labor and defense force by forcing young men and women to marry and have sexual relations in order to produce offspring. At the same time, the CPK implemented a policy to persecute and kill individuals and groups they believed opposed, or would by their inherent nature, oppose or be antithetical to their form of communist ideology. Those targeted for persecution and killing were deemed enemies of the CPK. These groups included those belonging to the former government or their forces, CPK members and rank-and-file soldiers and workers that they believed were traitors, the Vietnamese (who they viewed as lifelong enemies), the Cham Muslims (who they believed were unable to stop practicing religion), or any other individuals that they believed possessed traits which contradicted their socialist revolution. These included those possessing capitalist tendencies or those they believed were connected to foreign powers, particularly the United States and the Soviet Union.

A consequence of the implementation of these CPK policies was the removal of almost every fundamental human right recognized under international law. Rights such as the right to life, physical protection, expression, speech, association, movement, family, work, leisure and religion, among many others, were stripped from nearly every resident in Cambodia. As a result, Cambodians effectively became slaves of the CPK for more than three-and-a-half years. Alongside the crimes committed by the Nazis against the Jews and other minority groups in Europe during the Second World War, the nature and duration of the crimes of the Khmer Rouge, and the number of victims killed, raped and treated inhumanely make these crimes some of the worst in recent history.

With such a cruel, pervasive and complete attack on the humanity of a country it is difficult to understand why it took decades for any substantive national or international governmentsponsored judicial process to commence. There are three fundamental reasons why no such interventions were made. First, prior to the early 1990s there was a general lack of international co-operation and consensus on international issues, resulting from the politics of the Cold War. Second, it was only after a unique convergence of events- the large scale systematic serious human rights abuses being committed during the breakdown and conflict of the former Yugoslavia; the end of the Cold War; and the establishment of the International Criminal Tribunal for the former Yugoslavia (ICTY) in 1993- that the development of international criminal courts and tribunals as a response to mass atrocities became a reality. Third, the unstable political and military situation existing in Cambodia between the former Khmer Rouge forces and the newly formed Cambodian government continued until the late 1990s (when the Khmer Rouge leadership finally surrendered in full), which made it difficult to establish, investigate and bring to trial DK perpetrators.

Yet, after years of discussion between the Royal Government of Cambodia (RGC) and the UN over the power sharing of the judicial process and the guarantee of fair trial standards for any accused, to the surprise of many the ECCC finally became operational in July 2006. Everyone recognized that, with key suspects at an advanced age, and the crimes now having occurred decades earlier, the window for justice for these atrocities was closing fast. But importantly for many, that window was still open.

Fortunately, in the absence of a judicial process in the preceding 25 years to bring individuals to account for these crimes, the work of independent researchers, academics, journalists, investigators and analysts working within or outside key NGOs filled an important void, and ensured justice would be served for these crimes. Working independently or with organizations such as the Cambodian Genocide Project led by Gregory Stanton, the Cambodian Documentation Program led by David Hawk or the Documentation Centre of Cambodia (DC-Cam) led by Youk Chhang, these individuals in many capacities undertook thousands of witness and suspect interviews, and collected, collated, preserved, archived, copied and analyzed tens of thousands of Khmer Rouge documents and other materials produced contemporaneously to the crimes. A number of 
these individuals wrote heavily sourced articles and books on the DK period and the lead up to it. They were diverse individuals with a similar aim: to discover the truth of the events of the period. Combined, they wrote in-depth analyses of the crimes that were committed, the policies that promoted those crimes, the structure of the CPK party and the DK government, their systems of communication, the background and activities of those most responsible for the crimes, and the general and specific causes and motivations that led to those crimes.

The comprehensive archives and expert works produced as a result of this work have been invaluable in arriving at the truth of the criminal allegations in the ECCC cases. Indeed, the value of the archives was recognized by the UN Group of Experts Report which found that, based principally on an examination of DC-Cam files, a prima facie case against select DK leaders for international crimes could be made. In their 2004 report the Experts stated, "It is expected that the Chambers will rely heavily on documentary evidence. Some 200,000 pages of documentary evidence are expected to be examined. The bulk of that documentation is held by the Documentation Centre of Cambodia, an NGO dedicated to the research and preservation of documentation on crimes perpetrated during the period of Democratic Kampuchea." ${ }^{11}$

The expert articles and books produced on the DK period before the ECCC investigations started have also provided critical fast track insights into the DK period from nearly every perspective. This would otherwise have taken years to develop. Authors such as David Chandler, Ben Kiernan, Elizabeth Becker, Philip Short, Steve Heder and Nayan Chanda, among many others, have provided highly informative books that have guided the parties to relevant facts in the case, original documentation and witnesses. ${ }^{2}$ Various offices at the ECCC wisely hired some of these experts who had researched and written extensively on this period. Experts such as Craig Etcheson, Steve Heder, Ysa Osman, Meng-Try Ea, and a number of analytical staff from DC-Cam were employed when the court began. These staff significantly bridged the knowledge gap between the independent investigations and analysis done before the ECCC and the new investigation and legal teams who did not have that specialist knowledge prior to their arrival.

Before we review some examples of key evidence that was collected by individuals working on the DK period crimes pre-ECCC, I will outline the current status of the work of the ECCC, particularly in terms of the trials it has conducted over the last 11 years. These trials, as a result of the ECCC's personal jurisdiction as described in its founding Statute, could only be of individuals who were considered to be senior leaders and those most responsible for the crimes committed. So the number of prosecutions was inevitably aimed to be relatively small. Consequently, since 2006, there have been 10 individuals under judicial investigation and prosecution. Of these 10, three have been convicted of crimes in two separate trials and some of these convictions have been confirmed on appeal. The third trial at the ECCC, which is the second one against the accused Nuon Chea and Khieu Samphan, has been completed, with the judgment expected in November 2018.

The first of the three trials heard was against Kaing Guek Eav, otherwise known as 'Duch.' He was the officer in charge of S-21, a converted high school that became a torture and killing centre of the CPK for most of the DK period. Here, over 12,000, and it is now alleged that over 18,000 people were imprisoned in inhumane conditions, interrogated, tortured and executed over a threeyear period. For these crimes against humanity and war crimes, Duch received a 35-year custodial sentence with a reduction of 5 years as a result of his illegal detention prior to the establishment of the ECCC, ${ }^{3}$ which was increased to a life sentence on appeal ${ }^{4}$

\footnotetext{
${ }^{1}$ United Nations, Report of the Secretary-General on Khmer Rouge Trials, October 12, 2004 (UN Doc. A/59/432), para 19.

${ }^{2}$ For example, Nayan Chanda, Brother Enemy, the war after the war (New York: MacMillan Publishing Company, 1986); Ben Kiernan, The Pol Pot Regime: Race, Power, and Genocide in Cambodia under the Khmer Rouge, 1975-1979 (New Haven and London: Yale University Press, 1996); Elizabeth Becker, When the War was Over: The Voices of Cambodia's Revolution and Its People (New York: Simon and Schuster, 1998); David Chandler, Voices from S-21: Terror and History in Pol Pot's Secret Prison (Berkeley and Los Angeles: University of California Press, 1999); Steve Heder, Cambodian Communism and the Vietnamese Model: Imitation and Independence, 1930-1975 (Bangkok: White Lotus Press, 2004); Philip Short, Pol Pot: The History of a Nightmare (New York: Henry Holt \& Company, 2004).

${ }^{3}$ Kaing Guek Eav alias Duch, Trial Chamber Judgment, July 26, 2010, ECCC Case 001, Doc. No. E188, para. 631 \& 632.

${ }^{4}$ Kaing Guek Eav alias Duch, Appeal Chamber Judgment, February 3, 2012, ECCC Case 001, Doc. No. F28, para. 383.
} 


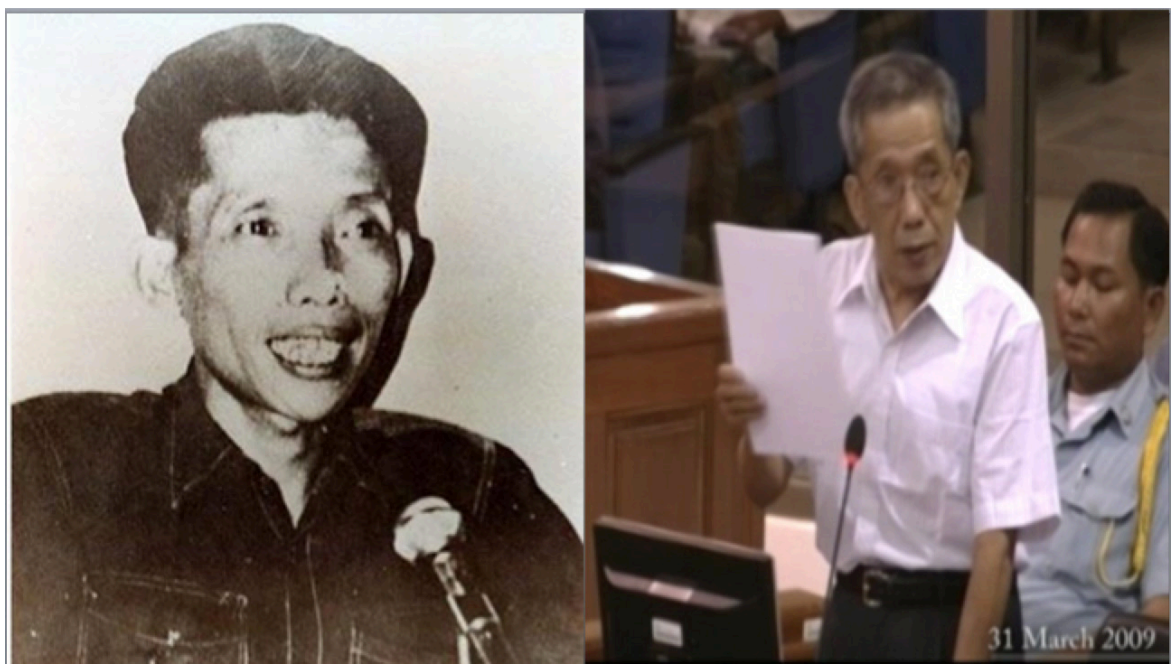

Figure 2. Kaing Guek Eav alias Duch providing training to his guards at S-21 during the DK period and then testifying at the ECCC approximately 30 years later.

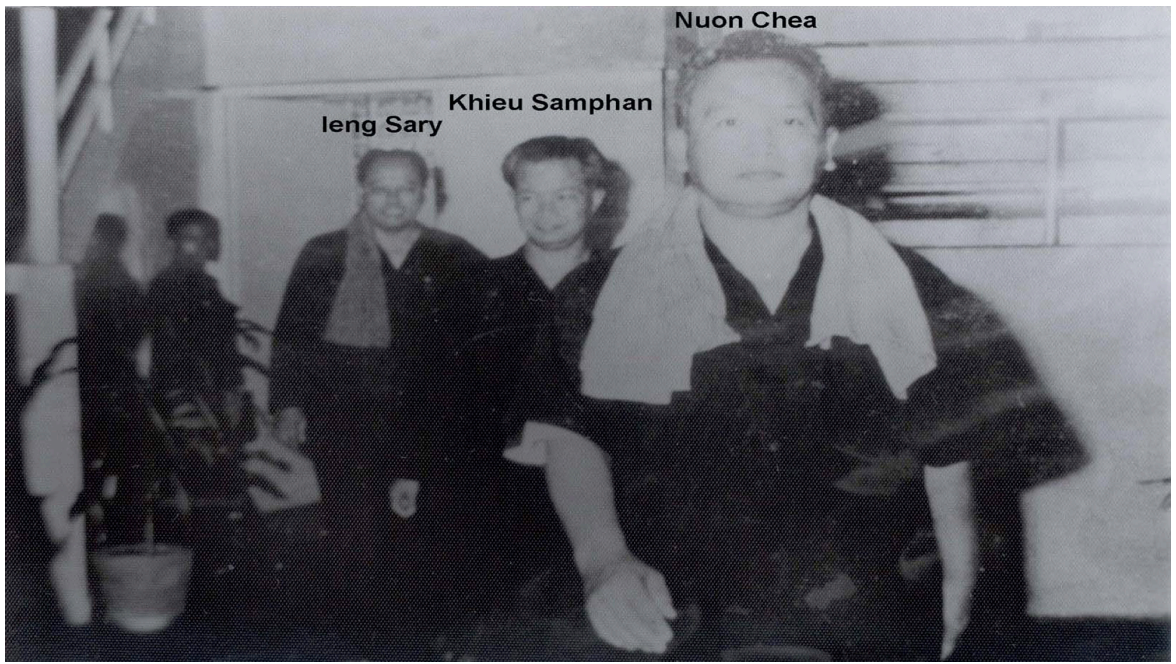

Figure 3. leng Sary, Khieu Samphan and Nuon Chea attending a CPK rally during the DK period.

The second trial was initially against four accused, Nuon Chea, Ieng Sary, Khieu Samphan and Ieng Thirith. However shortly before the trial began, Ieng Thirith was found mentally unfit to stand trial due to the onset of a severe case of Alzheimer's disease. Then, over a year into the trial Ieng Sary, the husband of Ieng Thirith, died from a number of conditions relating to his advanced age of 87. After a long trial, convictions were recorded against Nuon Chea and Khieu Samphan for crimes against humanity, of murder, persecution and other inhumane acts arising out of the forcible evacuation of between two million and three million people from Phnom Penh, and others across the countryside, in order to implement the CPK's socialist agrarian program. Both of the accused were sentenced to life, and despite revision of some convictions, the life sentences were upheld on appeal. ${ }^{5}$

The third trial was against Nuon Chea and Khieu Samphan, addressing their responsibility for the crimes of genocide, crimes against humanity and war crimes occurring throughout the whole

${ }^{5}$ Nuon Chea and Khieu Samphan, Trial Chamber Judgment, August 7, 2014, ECCC Case 002/01, Doc. No. E313, 622; Nuon Chea and Khieu Samphan, Appeal Chamber Judgment, November 23, 2016, ECCC Case 002/01, Doc. No. F36, 519. 
DK period. This trial has concerned itself with the allegations of enslavement and deaths through inhumane treatment at worksites, forced marriages and rape within those marriages, and the mass killing of individuals across the country inside and outside CPK security centres. The charges of genocide relate to Vietnamese and Cham Muslims living in Cambodia. The hearings of the third trial have finished and a verdict is expected in November 2018. It was originally planned to have one trial against the four senior leaders, however the Trial Chamber decided to sever the charges, resulting in two trials. ${ }^{6}$ Each trial dealt with two sets of representative charges in the closing order, ensuring that the combined impact of both trials properly represented the core types of crimes committed in the DK period. ${ }^{7}$

The two trials of Nuon Chea and Khieu Samphan have been particularly large, when measured against the time they have taken, the allegations they have covered and the evidence admitted in support. Combined, the two trials have taken 499 days, required the questioning of 278 individuals, 172 witnesses, 95 civil parties and 11 experts. Some 16,591 documents have been admitted, which include contemporaneous DK materials, analytical works, audio and video recordings, and interviews by the Co-Investigating Judges and DC-Cam. These documents range in size from single-page DK telegrams or photographs to books of several hundred pages.

The significant length of the two trials and the sizeable amount of evidence used to support the charges has been necessary for a few reasons. Proving crimes that occurred countrywide on a widespread and systematic basis some three decades earlier requires a detailed and thorough approach to the evidence both in terms of the content and volume of material collected. This comprehensive approach is also required to prove the causal link between the most responsible for the crimes and the perpetrators who physically committed them. To prove the link, proof is usually required of the organizational authority structure and communication systems through which the crimes were committed; proof of the policies that led to the commission of the crimes; and the role and activities of those leading the organizations to which the perpetrators belong. This evidence is often complex and difficult to obtain.

Finally, these mass atrocity cases are large due to the responsibility of the court to put the charges in a historical context, to determine the broader causes and motivations behind the commission of these crimes. It is essential that a society learn from its experience in order that history does not repeat itself. Although these issues may not be specifically necessary to prove the charges in the indictment, court findings on the broader causes and motivations behind the crimes have the potential to educate law makers, politicians and society on what societal conditions should be avoided in future to reduce the likelihood of similar crimes occurring again. Understanding these factors provides a more satisfactory outcome for the victims, and gives a more complete picture of why the crimes occurred.

I will now turn to the nature of the prosecution evidence that was used to prove the allegations at trial. In all three trials the prosecution used evidence from multiple sources, including witnesses, civil parties, expert and accused testimony, and statements made out of court produced by the ECCC investigators or other individuals or agencies; CPK documentary evidence produced contemporaneously with the crimes during the DK period, in print, photo and video form; other contemporaneous documents produced by other governments and NGOs; forensic reports of exhumations; books and articles. At the ECCC the Trial and Appeal Chamber has made clear, rightly, that out-of-court statements carry less weight than in-court testimony. ${ }^{8}$

Notably, CPK contemporaneous documents and admissions by the accused in video and print form have been extremely valuable for the prosecution in proving its case. As for the contemporaneous documents, they do not suffer from memory loss, which can occur with a witness, civil party, suspect or accused, particularly with the events occurring around three decades earlier. These documents have the ability to capture accurately the precise nature of the crime, the policies

\footnotetext{
${ }^{6}$ Nuon Chea and Khieu Samphan, Trial Chamber Severance Order, September 22, 2011, ECCC Case 002, Doc. No. E124, 4.

${ }^{7}$ Nuon Chea and Khieu Samphan, Trial Chamber Judgment, August 7, 2014, ECCC Case 002/01, Doc. No. E313, 622; Nuon Chea and Khieu Samphan, Appeal Chamber Judgment, November 23, 2016, ECCC Case 002/01, Doc. No. F36, 519.

${ }^{8}$ Nuon Chea and Khieu Samphan, Trial Chamber Judgment, August 7, 2014, ECCC Case 002/01, Doc. No. E313, para. 34; Nuon Chea and Khieu Samphan, Appeal Chamber Judgment, November 23, 2016, ECCC Case 002/01, Doc. No. F36, para. 296.
} 
that led to those crimes, the specific structure of the DK organization and systems of communication, and the true intent of the accused and other individuals with which he or she may share the same goals. Often in mass atrocity cases there is limited concern for self-incrimination by an individual to hide their criminal intent, due to an often-held belief that they will never be brought to justice. Consequently, statements written and made at the time of the crimes by perpetrators are often less guarded than statements made when a judicial process against an individual is likely.

Fortunately for the Prosecution, large numbers of CPK internal documents were left behind in Phnom Penh, at S-21 and a few other places, when the Khmer Rouge was forced to rapidly exit the city due to the accelerated Vietnamese invasion of Cambodia in early January 1979. Nuon Chea was well aware of the evidentiary value of the documents left behind at S-21 when he scolded Duch, his subordinate, in 1983 for not destroying the documents before Duch fled S-21. This comprehensive set of documents left at S-21 became vital evidence for the prosecution more than 25 years later in proving some of the charges against all three accused.

The types of documents left behind by the Khmer Rouge in Phnom Penh included the CPK Party Statute, Standing Committee Meeting Minutes, Central Committee Decisions, monthly or bi-monthly CPK policy magazines (also known as Revolutionary Flags or Youths), directives, guidelines, orders, letters, telegrams, photographs, videos, prisoner lists and execution lists, among others. The Revolutionary Flag and Youth magazines provided a continuous flow of the policies and propaganda that the CPK wanted to educate all CPK members to implement in their respective areas of responsibility. Speeches and articles pronouncing and detailing CPK policies, some criminal, were written, authorized or agreed to by the accused and other senior leadership of the CPK. Being able to attribute this information to the accused was important for the Prosecution.

Admissions made by the accused in recorded speeches both before, during or after the DK regime, and admissions made in video documentaries and memoir style books produced by them or for them, have been highly probative in proving the allegations charged. Many of these speeches were statements transmitted over DK radio and recorded in other countries. Many were recorded by international journalists, and many were part of documentaries made after the DK regime, where both accused, particularly Nuon Chea, were extremely candid about their roles in and agreement with many of the criminal policies charged, particularly the policy to kill individuals they believed were traitors, without trial.

Expert testimony and expert books and articles written by academic scholars and journalists have also been invaluable for the prosecution. Testimonies of authors of specialized or weighty and extensive research works, such as David Chandler, Phillip Short, Steve Heder, Elizabeth Becker, Kasumi Nakagawa, Peg Levine, Stephen Morris, Nayan Chanda, Ysa Osman, Alex Hinton, Craig Etcheson and Henri Locard, among others, have assisted the Trial Chamber and the parties to better understand the relevant evidentiary areas required to be proved or defended, and the relationship of original documents to these areas. These writings or testimonies also provide an opportunity for the parties to test alternative opinions both before and during trial. Experts have testified on topics such as the operation of S-21, CPK policies, authority structure and communication systems of the $\mathrm{CPK}$, the armed conflict with Vietnam, forced marriage and the commission of genocide, crimes against humanity and war crimes.

The prosecution at the ECCC has always acted with determination to ensure the maximum amount of evidence was made available to the parties and the Trial Chamber to determine the truth of the allegations. Where possible, the prosecution had the goal of requesting the admission, both during the investigations and trials, of as much contemporaneous documentary evidence and accused and other senior leader confessional evidence, along with expert opinions, as it could, in order to support and corroborate the essential witness and civil party evidence at trial. This was to ensure the prosecution met its responsibility to prove its cases beyond reasonable doubt. I would like to highlight some examples of this type of contemporaneous or confessional evidence that was used at trial to prove the charges alleged.

The first key allegation I will look at is the issue of the nature of the ideology, goals, authority structure and communication systems of the CPK- the CPK being the one-party government of Democratic Kampuchea. Proving these core functioning aspects of the Party enabled the Prosecution to argue more persuasively the nature and purpose of the CPK's criminal policies, 


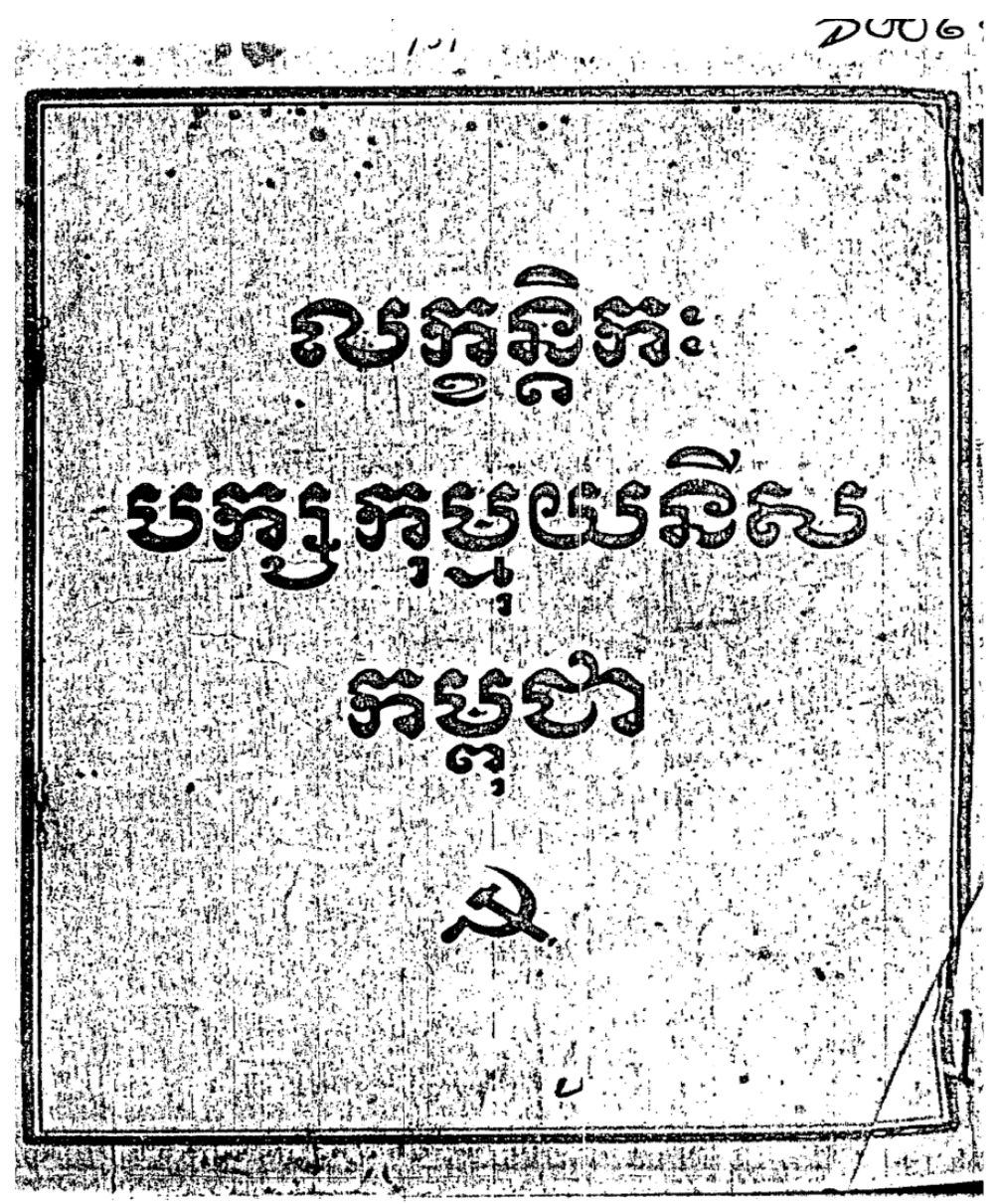

Figure 4. The front page of the Statute of the Communist Party of Kampuchea.

how they were implemented and who was criminally responsible for them. The high level of consistency of concepts and language on these issues between the CPK Statute and all of the other evidence at trial combined, as well as CPK documents, witness, civil party, accused and expert testimony, enabled the prosecution to argue with confidence the specific nature of the ideology, goals, policies, authority structure and communication systems of the CPK.

The clearest and most authoritative CPK document that assists in proving the ideology, visions, objectives, goals, duties and obligations of Party members, and the authority and communication structure of the CPK, is the Statute of the Communist Party of Kampuchea. ${ }^{9}$ Testifying at trial, Duch stated that the CPK Statute tendered in court was an amended version of a similar one that he had knowledge of prior to the DK period. Although the Statute does not explicitly outline the specific criminal policies with which the accused are charged, the Prosecution argued that by such membership to the Party, the accused agreed to its goals, objectives, structure and obligations on members, as outlined in the Statute.

In terms of the Party's objectives, the Statute outlines the following, "...to continue to make and to achieve socialist revolution in Kampuchea and to move forward toward Communism in Kampuchea in the future [and the Party] must defend the results of the revolution and defend and construct the country well."10 More specifically, regarding the nature of their ideology, the Statute indicates groups and characteristics of individuals that are likely to be in opposition to and

\footnotetext{
${ }^{9}$ The Statute of the Communist Party of Kampuchea (CPK Statute), 1976, ECCC Case 002 Doc. No. E3/130.

${ }^{10} \mathrm{CPK}$ Statute, Fundamental principles and political stances of the Party (Fundamental principles), 3.
} 
become enemies of the Party. It states "...[the Party] arms itself with...strong proletarian world views and life views, absolutely struggles against non-proletarian world views and life views and opposes the revolutions of the petty bourgeoisie, the capitalists, the feudalists, the imperialists and all reactionaries."11 Dealing with the concept of enemies further, the Statute places obligations on members to actively seek out enemies as a part of the social revolution, "....[the] Party must have high-level revolutionary vigilance towards all enemy activities and trickery, direct or indirect, overt or secret, which have the intent to destroy the Party by every means." ${ }^{12}$ This requirement highlights the pre-occupation, animosity, suspicion and readiness to take action against any individual with a different view, or aligned or perceived to be aligned, to a group that is not acceptable to the $\mathrm{CPK}$ ideology. Such a requirement of Party leaders and members underpins the motivation for the persecution and killing of suspected Cambodians and minority groups during this period.

The Statute further highlights the inflexible zealousness and speed within which CPK members were required to implement the social revolution. It states, "[E]very member of our Party, must [...] always be on the offensive, forging himself in the heat constantly, always agitating, attacking, and pushing constantly, inside the great, hot and deep revolutionary movement of the popular masses and the worker peasants...making socialist revolution and constructing socialism successfully as quickly as possible, keeping on moving forward toward Communism." ${ }^{13}$ This rigid and absolutist approach required to implement the CPK goals of "building" and "defending" the country supported the arguments that the crimes which arose out of CPK central policies were committed as a result of a system that allowed little leeway to oppose the policies imposed.

In terms of decision making, the Statute identified that the CPK leadership and members at all levels of hierarchy made decisions in a collective manner, stating "...the Party leadership organizations must implement collective leadership and have specific persons holding responsibility" requiring that "various decisions of the Party must be made collectively." 14 This principle provided an insight to the prosecution as to how decisions were made and consequently how often decisions required agreement with more than one person. This was a relevant factor for the Prosecution in arguing the liability of Nuon Chea and Khieu Samphan for criminal decisions arising out of meetings in which they participated as part of a Committee. Based on this principle we argued that decisions emanating from those meetings could be imputed to all who were on that committee.

In terms of the authority and reporting structure, the Statute demonstrated that the CPK had a strict structure and reporting system that created onerous responsibilities on each member at all levels to fully inform their subordinates and superiors of their activities, criminal or otherwise. Regarding the authority structure, it requires that "... [t] he minority respects the majority. Lower echelon respects upper echelon. The individual respects the collective. The private respects the organization. The various echelon organizations respect the central organization."15

Regarding reporting obligations, the Statute requires "...[a]t the designated times, lower echelon must report to upper echelon on the situation and on work done. Also at each designated time, upper echelon must report to lower echelons regarding the general situation and regarding instructions which they must carry out."16 The prosecution argued that this reporting and communication structure provided strong evidence of ordering, agreement and knowledge of the commission of the various crimes across the country due to this inflexible top-down authority structure and the continuous top-to-bottom and bottom-to-top communication system that was to be enforced.

I would now like to turn to some illustrations of contemporaneous evidence and statements by the accused that were used to prove crimes arising out of CPK policies or the accused's participation

\footnotetext{
${ }^{11}$ Ibid., 4.

${ }^{12}$ Ibid.

${ }^{13}$ Ibid., 5.

${ }^{14}$ CPK Statute (1976), Article 6 (2), 16.

${ }^{15}$ CPK Statute (1976), Article 6 (4), 16

${ }^{16}$ CPK Statute (1976), Article 6 (5), 16.
} 
in them. First, turning to the forced evacuations of the residents of Phnom Penh to the countryside in the first few days of the Khmer Rouge takeover on 17 April 1975, admitted photos provided highly probative evidence of the evacuation itself and the forced nature of it.

The photos clearly demonstrated from the air and ground the arrival of the Khmer Rouge into Phnom Penh and the hope for a better future, then the immediate mass evacuation of the city in the first two days of the takeover, and following this, the complete emptiness and desolation of the city only a few days later. These photographs and videos depicted columns of people, young, old and sick, leaving on foot or being carried under armed guard with few or no possessions, leaving in a sea of humanity down the main roads exiting the city. The photos taken shortly after depicted barren, wide, main streets where not a car or person could be seen. These before photos, and the after shots of completely empty streets where not a person or car could be seen corroborated the forced and inhumane conditions under which the population was evacuated testified to be witnesses and civil parties. At the same time, these photos provided clear evidence of the power and discipline the CPK leadership had over its rank-and-file soldiers to perform such an operation.

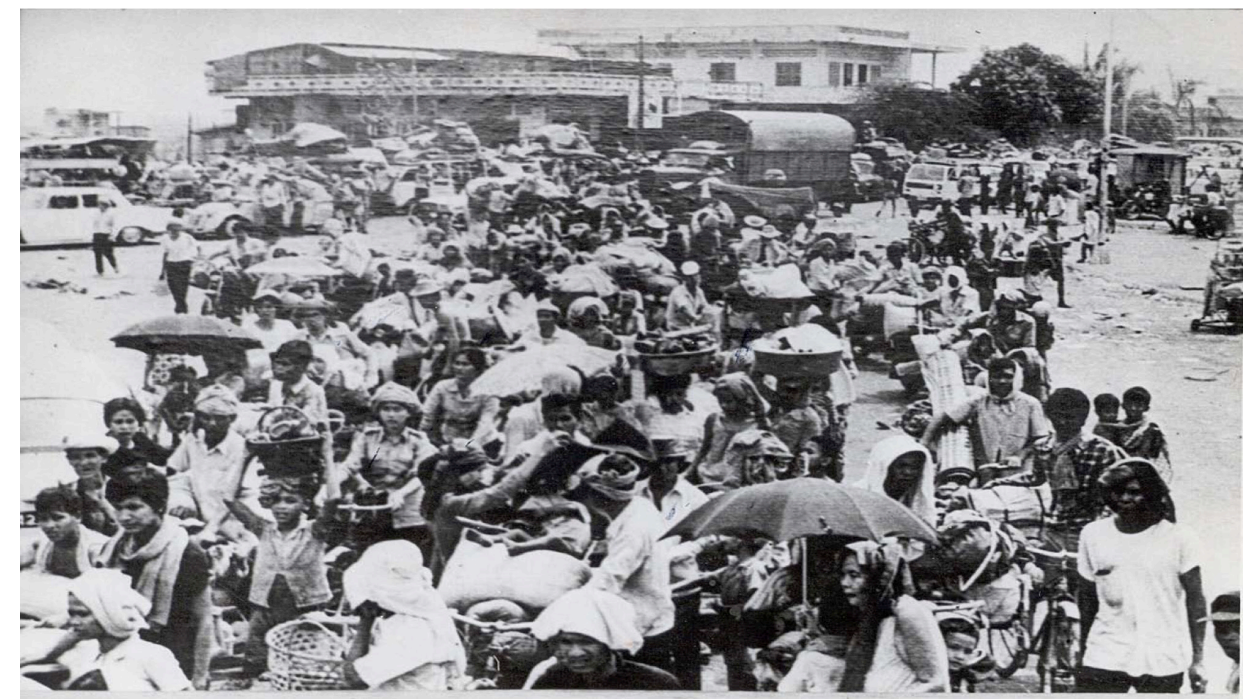

Figure 5. The evacuation of the residents of Phnon Penh when the Khmer Rouge took control of the city in April 1975.

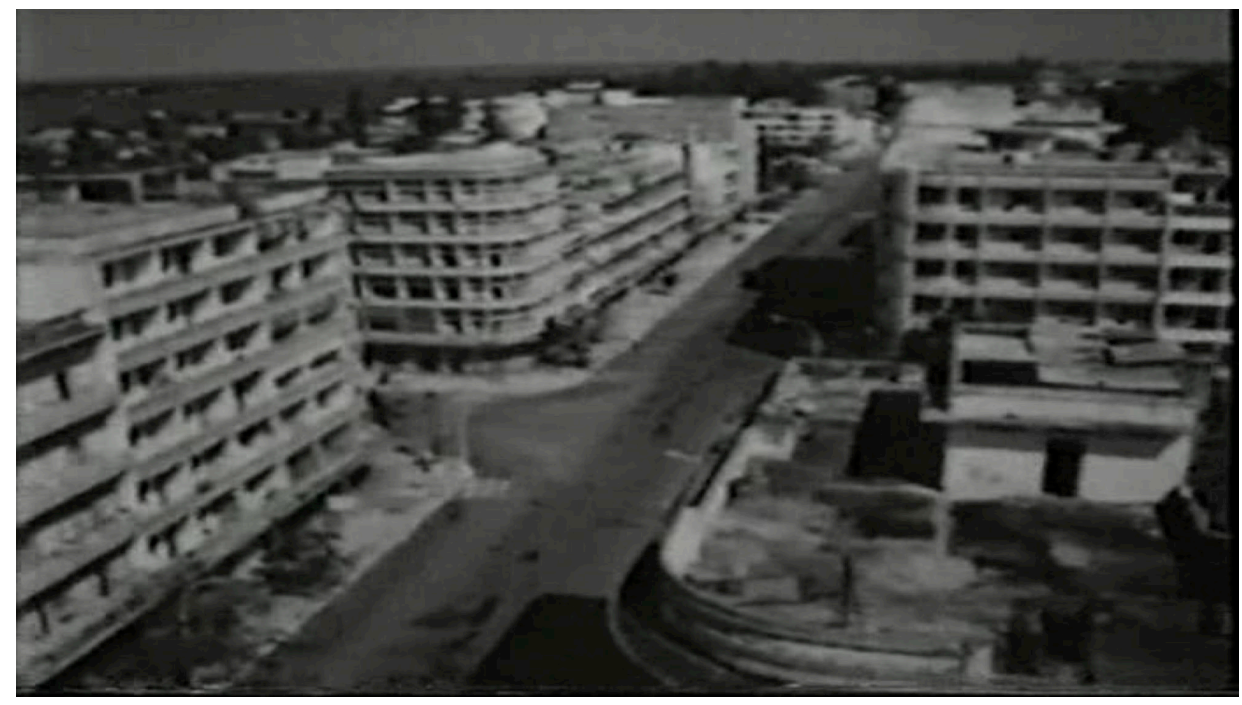

Figure 6. A photo taken shortly after the residents of Phnom Penh were forcibly transferred to work camps in the countryside in April 1975. 
Contemporaneous DK documents such as the February-March 1976 edition of the CPK Revolutionary Flag magazine confirmed the forcible nature and purpose of the evacuation, stating, "After the liberation of the entire country, nearly 3 million people had to exit the various cities empty-handed, without food supplies, without any means and tools at all to increase production. ${ }^{17}$ One of the accused, Ieng Sary, the Minister of Foreign Affairs and CPK Standing Committee Member admitted that, "The first months of the liberation were quite tough; 2000 to 3000 people died through the evacuation of Phnom Penh and several thousand died at the paddy fields." Khieu Samphan also admitted that he "clearly realized that the population might have fallen along the way." 18 Other contemporaneous material such as communications from embassies at the time and notes taken by foreign journalists present in Phnom Penh, particularly those of Sydney Schanberg, ${ }^{19}$ all provided valuable corroboration to the victim and witness testimony of the forced and inhumane nature of the evacuation.

Second, turning to the enslavement of Cambodians in worksites and communes across the country, which led to the death and serious physical and psychological injury of the workers, the video and photographic evidence brought into the courtroom the reality of the witness and civil party testimony. The video clips showed thousands of Cambodians, including children and the elderly working in large-scale agriculture projects under deplorable conditions. The video of the work done on these building and irrigation projects shows the speed, discipline and arduous nature of the work. When witnesses described suffering inhumane conditions in a number of cases leading to the death of workers, their conclusions that they were being "treated like animals" rang true.

The pressure under which the CPK put the workers to produce can be seen in the CPK meeting minutes of 30 September 1976, where it is recorded that the CPK must "whip up the mass movement, vigorously, and strictly directly on the human and material forces, in order to accomplish the 3 tonnes per 1 acre plan and to achieve the plan to build $30 \%$ of irrigation system countrywide." In a speech on 15 April 1977, Khieu Samphan admitted to the size of the worksites and the standard of living, stating that each construction site of a reservoir, canal or dam "is manned by as many as 10,000, 20,000 or even 30,000 workers... we have no machines. We do everything by mainly relying on the strength of our people... Though barehanded, they can do everything." ${ }^{20}$ Later, shortly before his detention at the ECCC he admitted to the forcible nature of the work, "In the co-operatives, the people were not free" corroborating witness testimony that they were in a "prison without walls" in DK. ${ }^{21}$

Third, turning to the forced marriage and rapes arising out of those marriages, photos of one ceremony provided an insight into the circumstances under which witnesses and civil parties described these forced marriage ceremonies. Two photos showing over 40 men and women being married, lined up, with no emotion, in the same uniform, same haircuts for men and women, in a bare hall with the only decoration being a large flag containing the communist symbol of a hammer and sickle, strongly supported testimony that marriages were forced. A CPK contemporaneous document, a Revolutionary Flag magazine dated 2 June 1975, made clear that marrying and procreating was under the control of the CPK: "In the matter of building a family, no matter the outcome of the Organization's and the collective's assessments and decisions, they must be absolutely respected." The forced aspect of the marriages was further confirmed by Nuon Chea to Thet Sambath, a Cambodian journalist, when he told him: "The man always wants to choose a

\footnotetext{
${ }^{17}$ Communist Party of Kampuchea, Revolutionary Flag, February - March 1976, ECCC Case 002 Doc. No. E3/166, 19.

${ }^{18}$ Written Record of Interview of Khieu Samphan, December 14, 2007, ECCC Case 002 Doc. No. E3/210, English Evidence Reference Number, 3.

${ }^{19}$ Sydney H. Schanberg, Cambodia Diary 1975: A journalist's day-by-day notes on the fall of Cambodia to the Khmer Rouge, ECCC Case 002 Doc. No. E3/9749, 72. For example one entry under 17 April stated "The boulevard is a sea of refugees, bend under sacks of belongings, their eyes hurt with the fear that being soft city people, the trek may kill them."

${ }^{20}$ Foreign Broadcast Information Service (FBIS) Speech of Khieu Samphan at Anniversary Meeting, April 15, 1977, ECCC Case 002 Doc. No. E3/200, 3.

${ }^{21}$ Meng Trea Ea and Sopheak Loeung, Note Takings Khieu Samphan and Nuon Chea, Pailin, Cambodia, June 9-11, 2006, ECCC Case 002, Doc. No. E3/108, 4.
} 


\section{Revolutionary Flag Feb - Mar 1976}

"after the liberation of the
entire country, nearly 3 million
people had to exit the various
cities empty-handed, without
food supplies, without any
means and tools at all to
increase production."

E3/166 Revolutionary Flag, February-March 1976, at ENG 00517831

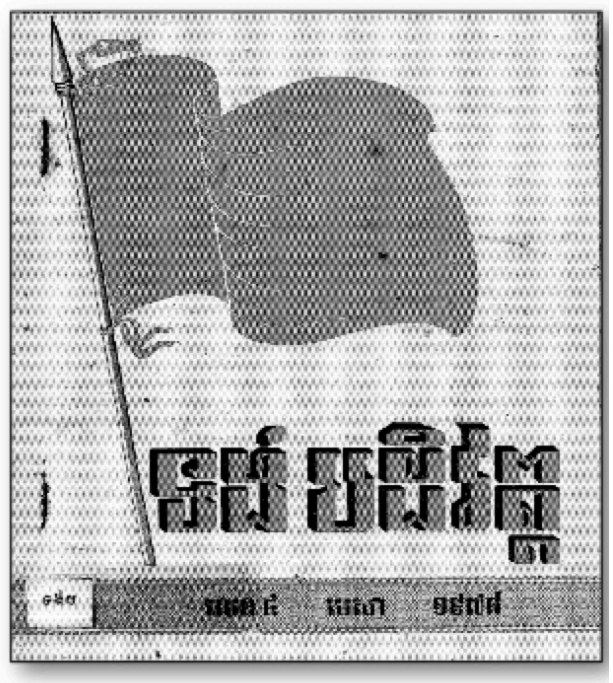

Figure 7. An excerpt from the CPK February to March 1976 Revolutionary Flag magazine where the forced transfers of the population a year earlier are discussed.

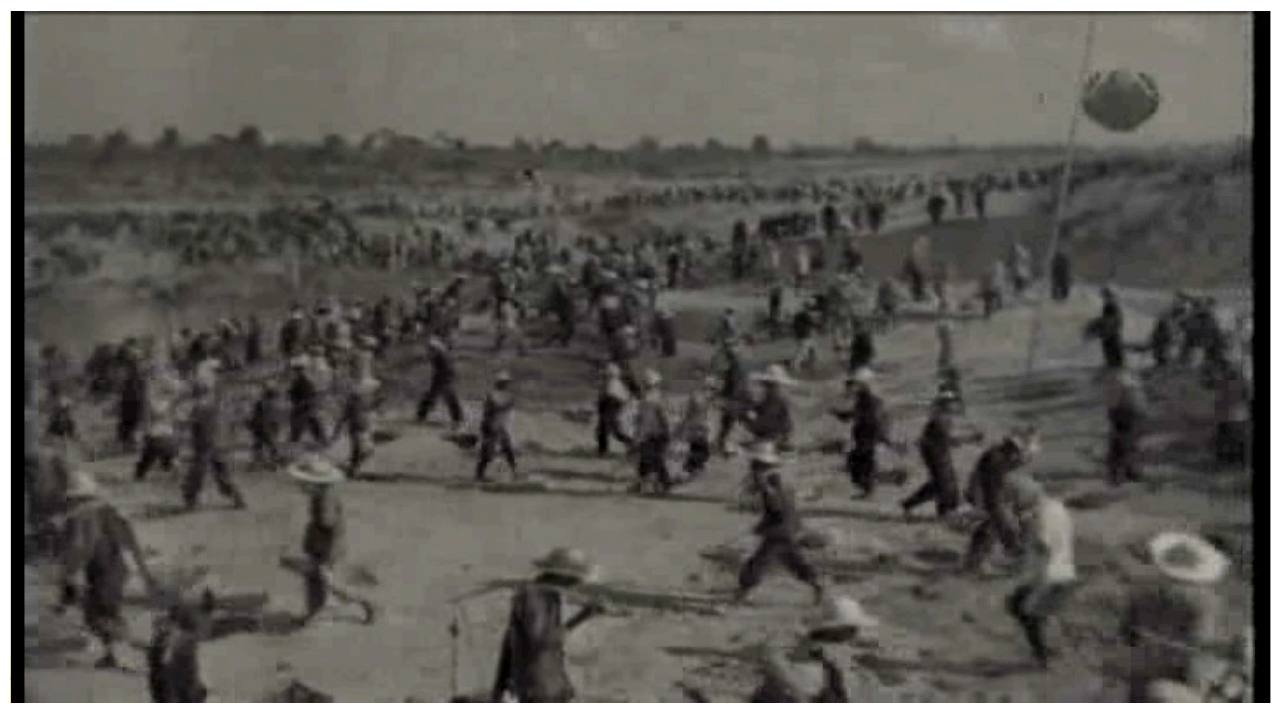

Figure 8. A photo of Cambodians detained at work sites where they were forced to labor under inhumane conditions.

beautiful girl, so that's why we forced them to get married and Angkar chose he wife."22 In the DK period the word "Angkar" took on a number of meanings, but it was generally used to mean the leadership of the CPK. This type of document and admission by the accused strongly corroborated the many witnesses and civil parties from across the country who stated they were forced to marry and have sexual relations against their will. These forcible sexual relations were charged as rape.

\footnotetext{
${ }^{22}$ Gina Chon \& Thet Sambath, Behind the Killing Fields (Philadelphia: University of Pennsylvania Press, 2010), 41.
} 


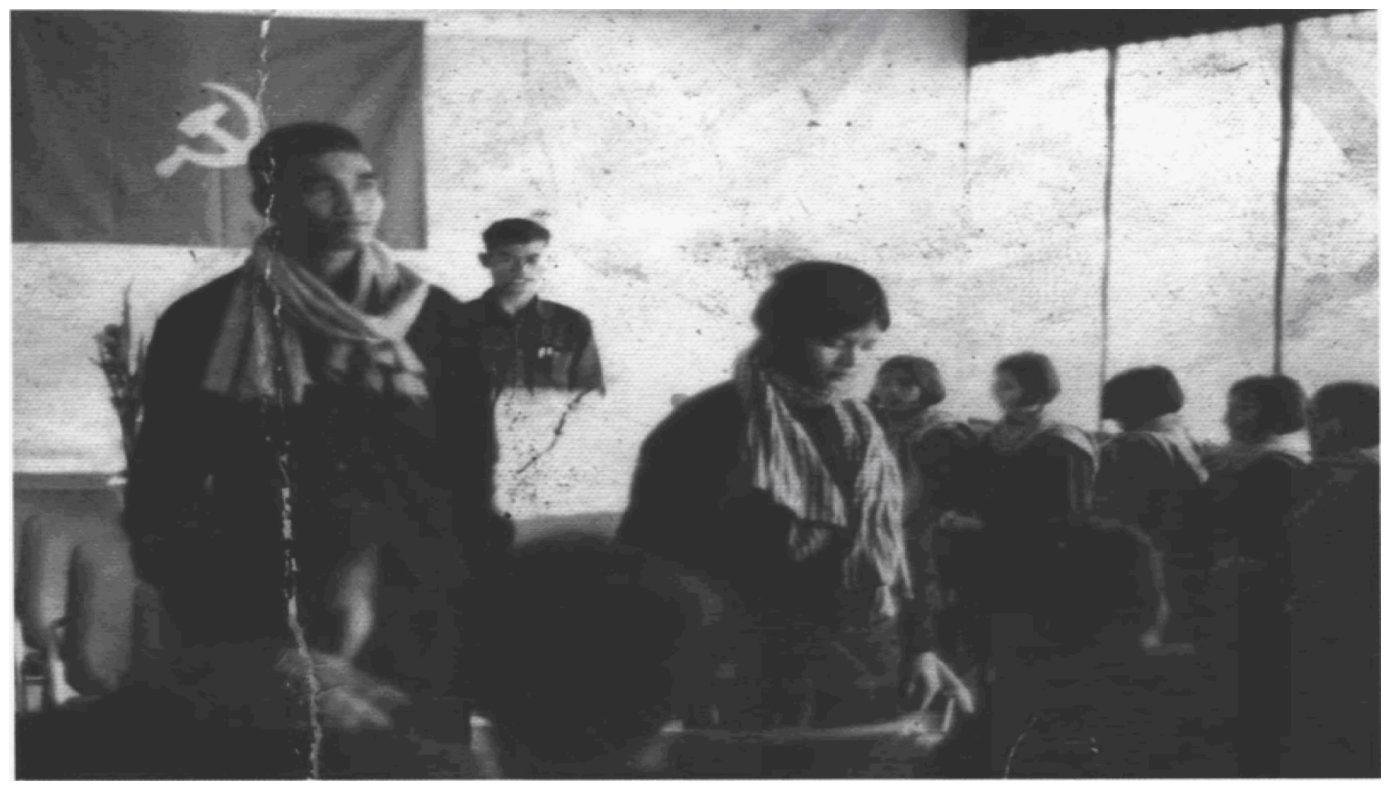

Figure 9. A photo of two young Cambodians being forcibly married.

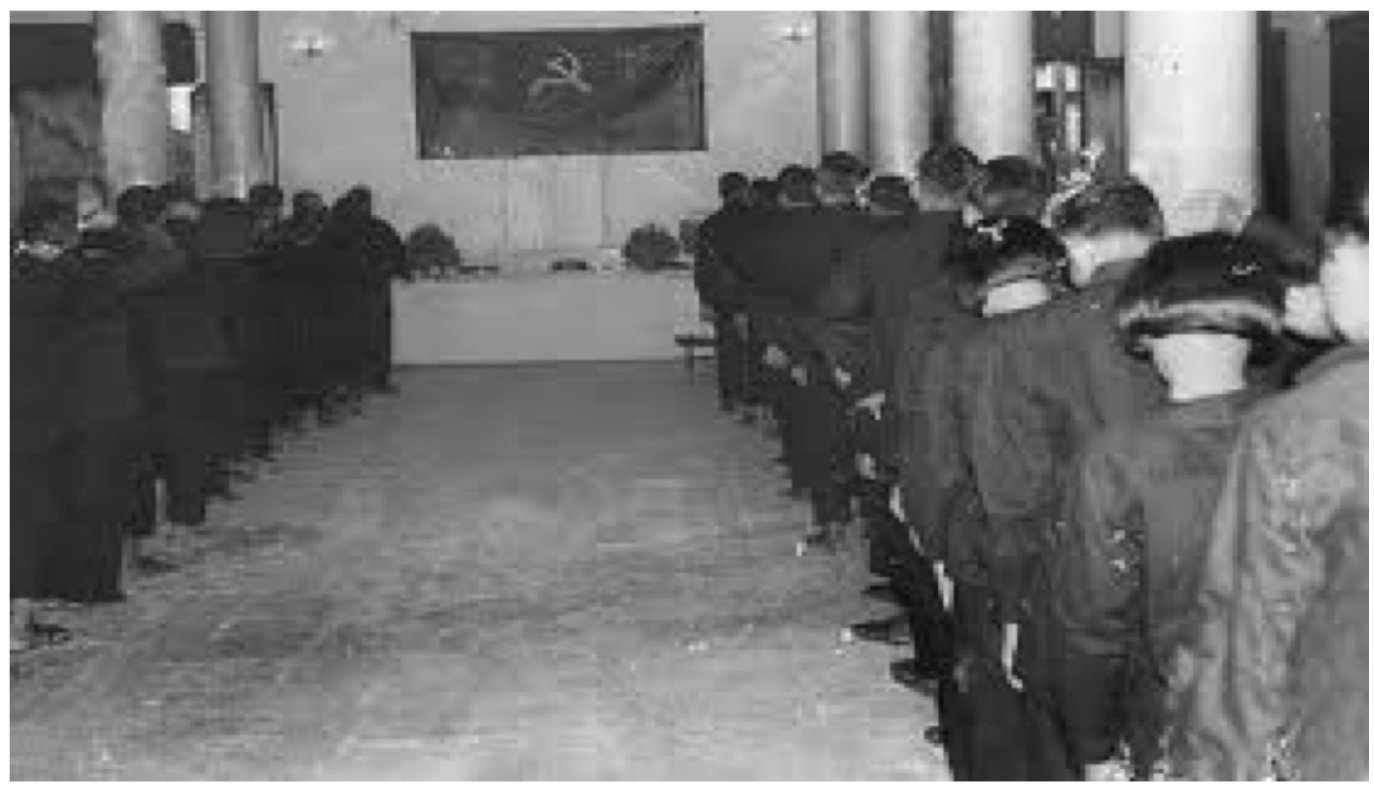

Figure 10. A photo of a forced wedding ceremony under the Khmer Rouge.

The driving force behind the forced marriage policy can be seen in statements of the accused made both during and after the DK regime. On 15 April 1978, Khieu Samphan stated it was a clear goal of the CPK at that time to "grasp firmly and implement well the plan to increase the size of the population to its maximum, so as to have $15-20,000,000$ people in the next $10-15$ years." ${ }^{23}$ Similarly, Nuon Chea in 1981 stated that DK "has pursued a policy of increasing its population... Since 1975 Democratic Kampuchea has always required a rapid increase in its population. Thus, the four-year

${ }^{23}$ Foreign Broadcast Information Service, Phnom Penh Rally marks $17^{\text {th }}$ April Anniversary, April 15, 1978, ECCC Case 002, Doc. No. E3/562, 7. 
plan of 1977-1980 aimed at increasing our population to at least 15,000,000 within 5 to 10 years."24 Consequently, when the prosecution argued that civil party and witness testimony of forced marriages and forced sexual relations occurring around the country were not ad hoc, but part of a systematic central policy, these contemporaneous documents were invaluable in supporting that argument.

Fourth, turning to the CPK policy to kill Cambodians and other groups under the façade that the CPK was "defending the country" the Prosecution relied upon on photos, videos, CPK documents and the accused's own statements. Although there were many debates at trial as to the number of killings and the purpose of the killings, ultimately the fundamental issue of the large-scale killings of civilians and protected persons from all national, racial, ethnic, religious and political groups boiled down to whether or not it was a legitimate exercise to kill people the CPK suspected or believed were enemies or traitors. Nuon Chea argued that such killings were legal and the Prosecution argued that such an argument was abhorrent, having no legal base in international criminal law. ${ }^{25}$

One of the key documents that demonstrated the intent of the leadership to authorize the killing of enemies without due process was a decision made on 30 March 1976 to different CPK committees across the country. The decision delegated "[t] the right to smash [kill]...in absolute implementation of our revolution, [and to] strengthen our socialist democracy" to the Standing, Central, Zone and General Staff Committees located in Phnom Penh and around the country. The clarity and absolute authority provided in this document and other similar documents promoting the killing of enemies without trial was the reason why so many people were killed in Democratic Kampuchea. The absolute power to kill by this decision was now distributed to delegated authorities across the country.

One of the locations where the prosecution proved the murders occurred as a result of this killing policy was at S-21, the torture and killing centre in Phnom Penh where at least 18,000 people were detained and executed.

The thousands of documents left behind have been powerful not only to show that mass killings occurred, but that they occurred as a result of policies, and those policies were created and agreed to by the senior leadership. A full range of CPK documents were discovered at S-21. These documents allowed the Prosecution to prove areas in the cases that not only related to S-21, but to crimes committed elsewhere across the country. The documents assisted in proving that the killings at S-21 were authorized by individuals at the highest level of responsibility, the nature of the killing policies that existed, and the identity, number and type of victims killed.

For example, one of the many thousands of prisoner and execution lists found at S-21, dated 17 February 1977, recorded an instruction from Duch to his subordinate. The annotation on the list stated; “(1) Smash: 115 (2) Keep: $23+21$ = persons. Comrade Duch proposed to Angkar. Angkar agreed." This singular document, we argued, assisted in proving the death of 115 prisoners and that a member or members of the Standing Committee ordered the killings, or were at least aware of them.

Allegations of torture were also corroborated through the use of S-21 documents. On one confession from S-21 the annotation stated, "Brother Duch, Here are the responses of Phoas, given when we whipped him 4-5 times to break his stances before taking him for waterboarding. Respectfully, Pon, 14 April 1977." Other annotations on "confessions" of prisoners assist in demonstrating that Nuon Chea and other senior leaders were aware of the existence of S-21 and the interrogations, tortures and killings occurring there. One annotation on a confession stated, "One copy sent to Brother Nuon [Nuon Chea] on 10 September 1977." One explicit annotation by Duch to his subordinate that appeared on a prisoner list provided highly probative evidence of the criminal nature of S-21, where it stated, "Uncle Peng, Kill them all, Duch 30/5/1978."

\footnotetext{
${ }^{24}$ FBIS, Interview with DK Leader on Population Policy and Struggle Against Vietnamese, October 27, 1981, ECCC Case 002, Doc. No. E3/686, 11.

${ }^{25}$ Nuon Chea's Submissions on the Relevance of Evidence of Treasonous Rebellion to His Individual Criminal Responsibility, June 10, 2016, ECCC Case 002, Doc. No. E395/2, para. 30; ECCC, Co-Prosecutors' Amended Closing Brief, Case 002, Doc. No. E457/6/1/1, 27, para 72.
} 


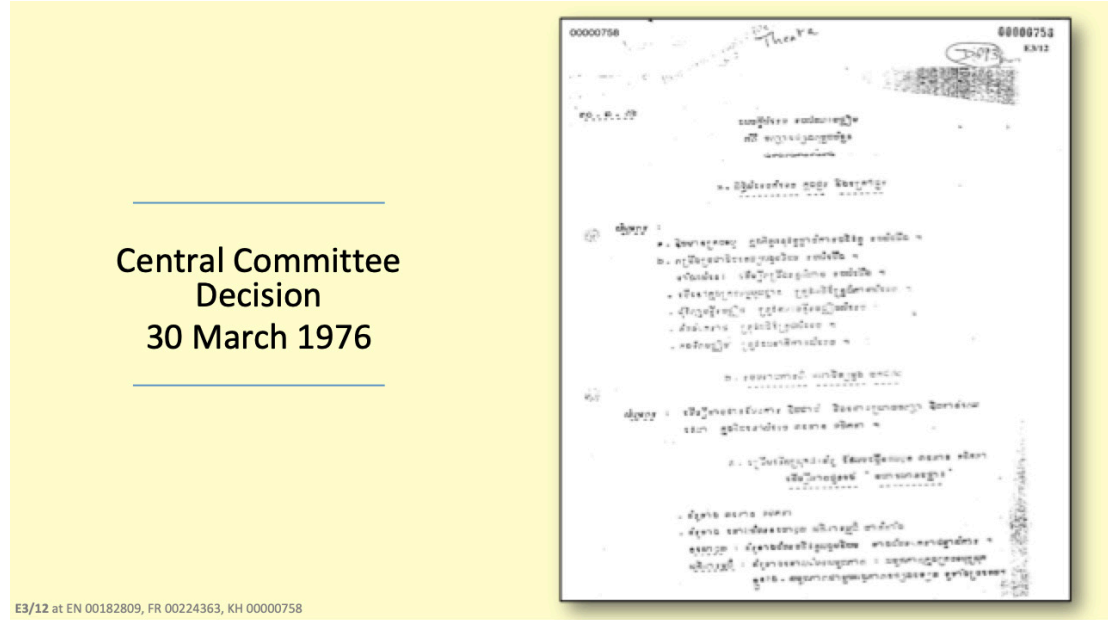

Figure 11. The Central Committee Decision of 30 March 1976 delegating the authority to kill to Zone Committees and other specialist Committees.

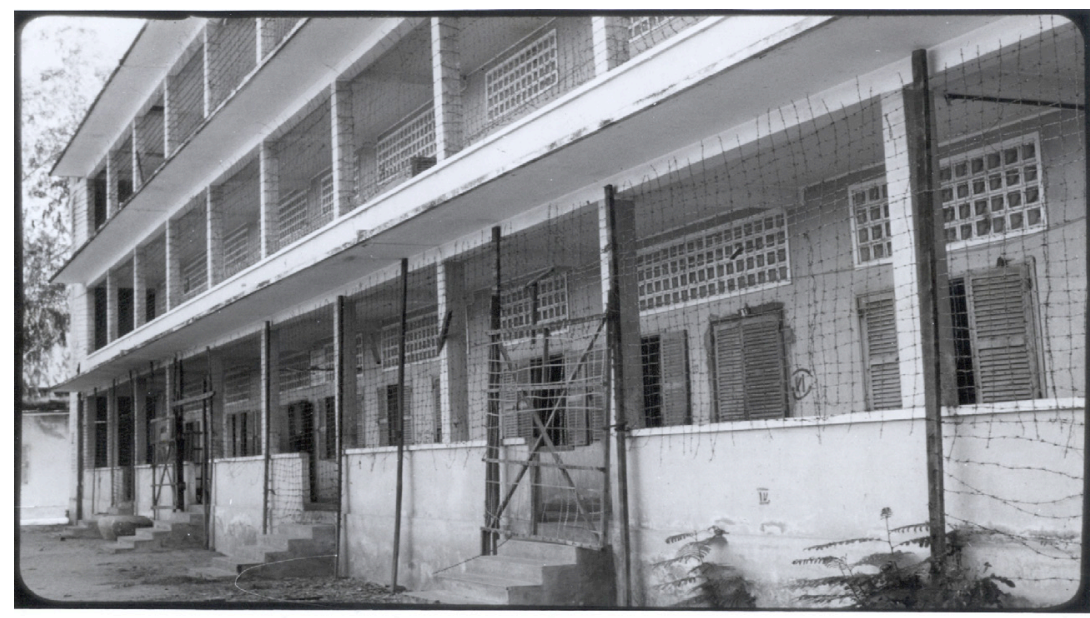

Figure 12. A photo of the outside of S-21 taken shortly after the Khmer Rouge were ousted from power in 1979.

Of the approximately 189 prisons or security centres that were known to have existed during the DK period, the prosecution in the second trial of Nuon Chea and Khieu Samphan concentrated on proving the inner workings of four of them, including S-21. One of those other security centres was a place called Kraing Ta Chan in the Tram Kak District, where many thousands of prisoners were killed. Assisting in demonstrating the number of prisoners killed there was a document from the prison chief that stated, "We have so far smashed 15,000 enemies. Please be informed accordingly. District Re-education Office 105, An."26

In any criminal case, a confession from an accused taken in unequivocally voluntary circumstances is powerful evidence. Thet Sambath interviewed Nuon Chea for many years on video prior to Nuon Chea arriving in ECCC custody. Thet Sambath then produced a publicly available documentary called Enemies of the People, in which Nuon Chea makes some of the most candid admissions as to his role, knowledge and implementation of the CPK's killing policy. ${ }^{27}$ The documentary is full of admissions as to his role in the decisions to kill people perceived to

${ }^{26}$ Notebook from Kraing Ta Chan Security Office, 1977, ECCC Case 002 Doc. No. E3/2107.

${ }^{27}$ Rob Lemkin, dir., Enemies of the People (2010; UK and Cambodia: Old Street Films), documentary, 93 min. 


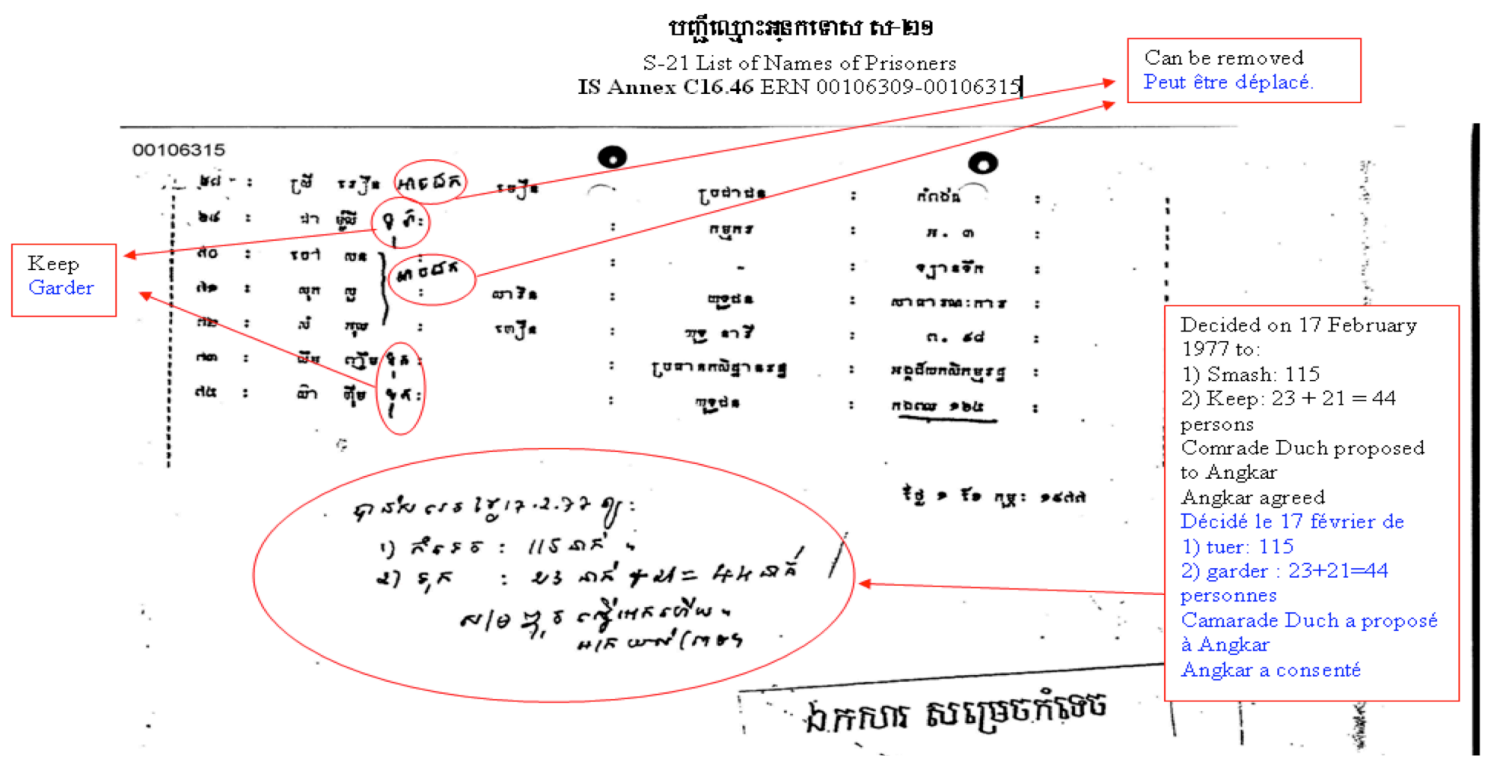

Figure 13. A copy of an S-21 prisoner list where Duch provided instructions to kill or keep the detainees for further interrogation.

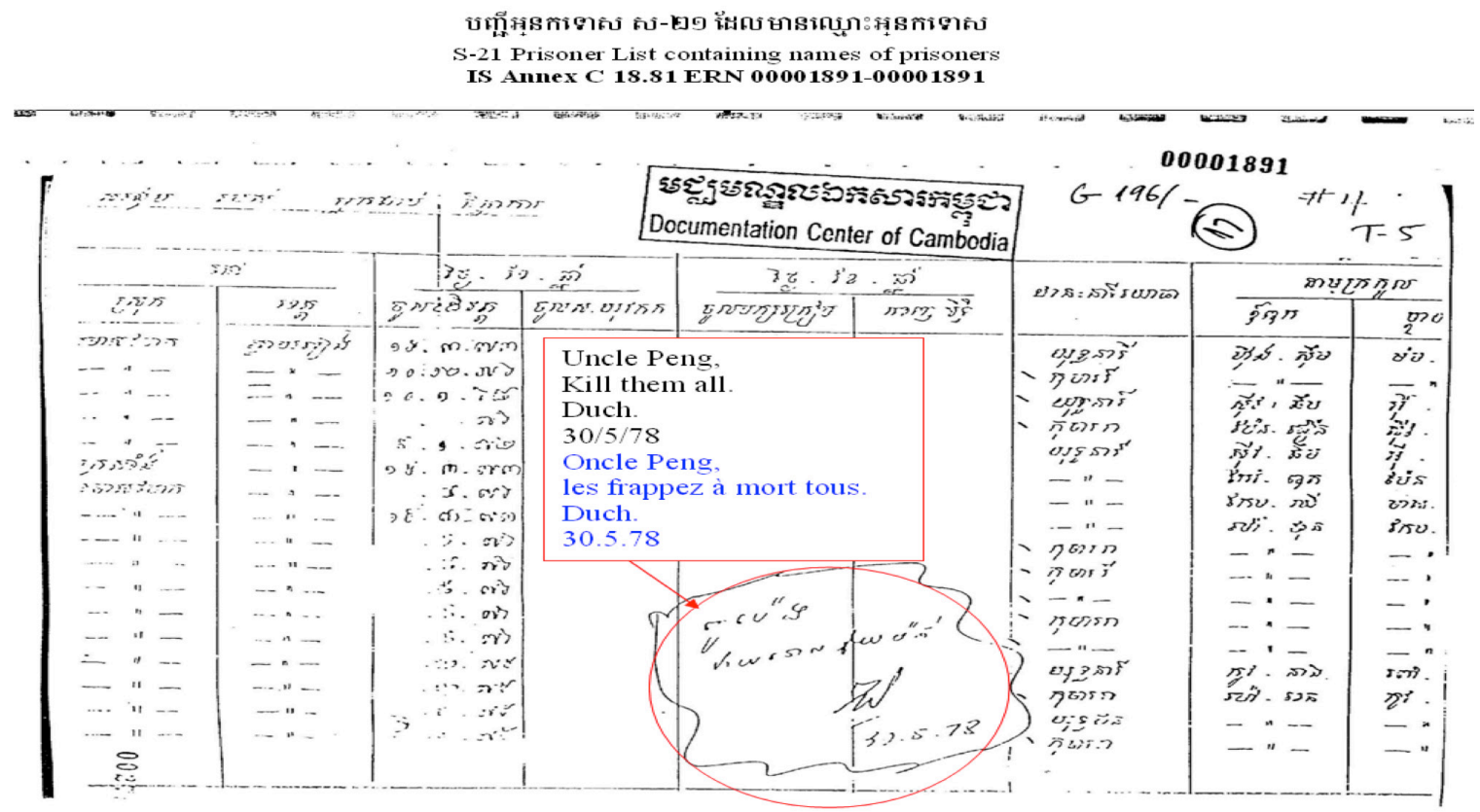

Figure 14. A copy of an S-21 prisoner list where Duch instructs his subordinate, "Uncle Peng” to kill them all.

be enemies of the CPK, for example he stated, "The Party decided to kill them because they were betraying the party and the nation. I was not scared or sad when they were killed. They had done wrong and betrayed us, so they received the kind of treatment they deserved." As to the lengths Nuon Chea would take to preserve his own life and other senior leaders, Nuon Chea stated in July 1978 to the Communist Workers' Party in Denmark, "[t]he leadership apparatus must be defended at any price ... There can be no comparison between losing two or three leading cadres and 200-300 members. Rather the latter than the former." 
I would now like to turn to some further illustrations of contemporaneous documentary evidence and admissions by the accused tendered to show Nuon Chea's and Khieu Samphan's participation in the crimes charged. Regarding Nuon Chea, the prosecution argued that as a result of Nuon Chea's second most senior position in the CPK and DK, and his role and activities in the CPK, including the creation and promotion of its criminal policies, Nuon Chea was a central participant in a joint criminal enterprise to commit the crimes charged.

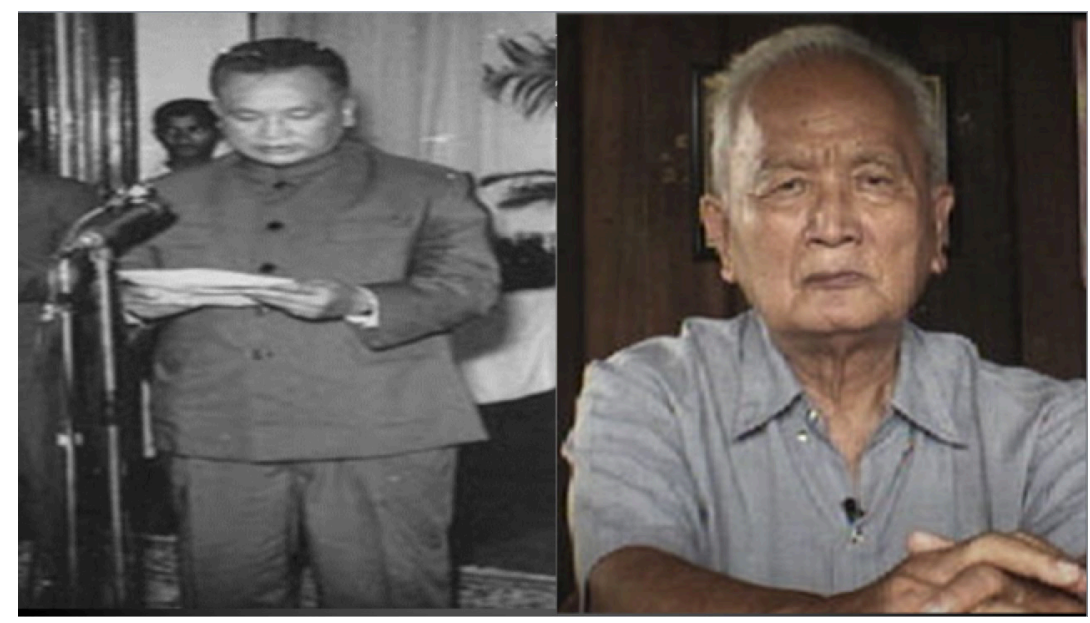

Figure 15. Nuon Chea giving a speech during the DK period and then being interviewed approximately 25 years later before he was arrested and detained at the ECCC.

Nuon Chea was the Deputy Secretary of the CPK and a leading Standing Committee member, with this committee having the highest decision-making powers in the CPK and DK. In the Thet Sambath documentary Enemies of the People, Nuon Chea, not denying power but in fact taking pride in it, stated he and Pol Pot, the Secretary of the CPK, were at the same level. He said " $[\mathrm{t}]$ hey just called him and me Brother Number One and Two... I was not the right arm or the left arm of Pol Pot... We were equal. Pol Pot did not serve me and I did not serve him. We both served the way of the Party." As to being central to creating CPK policies and agreeing to them, Thet Sambath wrote of the relationship between the two, "During their years in power, the two were nearly inseparable, spending much more time with each other than they did with their families or other leaders. Before any new initiatives were presented, Pol Pot and Nuon Chea always discussed them together to hammer out the ideas and make sure they agreed on every point." 28 This evidence, taken from Nuon Chea's interviews with Thet Sambath was powerful in proving the joint criminal enterprise between Pol Pot and Nuon Chea, the two individuals holding the highest positions in the CPK at the time.

In terms of Khieu Samphan's role in the crimes charged, the prosecution argued that Khieu Samphan also worked closely with Pol Pot and Nuon Chea in his role as the DK Head of State, his central role in Office 870 (the political and administrative committee that implemented the decisions of the Standing Committee) and his role in the Commerce Committee. As a result of his position, roles and activities, in these positions and the CPK more generally, the Prosecution argued that Khieu Samphan significantly contributed to the joint criminal enterprise with Pol Pot, Nuon Chea and others to commit the alleged crimes.

Khieu Samphan's own admissions in his book about his relationship with Pol Pot corroborated the other evidence at trial. Khieu Samphan wrote, "As for daily life, Pol Pot and Nuon Chea had

${ }^{28}$ Chon and Sambath, Behind the Killing Fields, 135. 


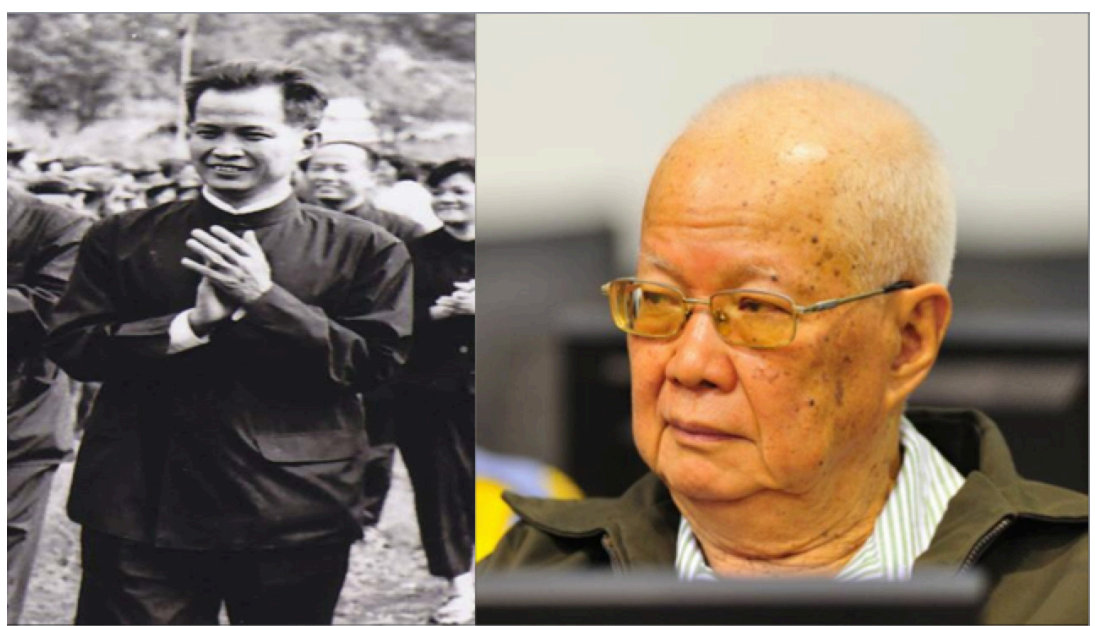

Figure 16. Khieu Samphan on official duties in the DK period and then sitting in a trial session at the ECCC approximately 35 years later.

meals with me, and we had meals together. We did nothing separately." ${ }^{29}$ When interviewed in a television documentary, Khieu Samphan stated that he respected Pol Pot and viewed him as a "great leader" and said he "followed him all the time, like a shadow." ${ }^{30}$ Becoming teary on the video footage, he said, "I can still see him in the Cardamon Mountains, here and there. I always keep a clear image of him in my head." ${ }^{31}$ When asked by the interviewer if he missed Pol Pot, Khieu Samphan answered, "Yes, because he had such an exceptional mind." ${ }^{2}$ It was quite clear from these videos that Khieu Samphan was in awe of Pol Pot. Such emotion and candidness is often very difficult to obtain during the trial due to the official nature of the atmosphere and the more circumspect approach that the accused is likely to adopt.

Khieu Samphan's agreement with the killing policies and active participation in promoting them can be seen in many speeches during the DK period to high-level CPK cadre from around the country. One of those speeches at the 1978 anniversary records Khieu Samphan demanding that cadres pledge "[t]o exterminate resolutely, all agents of the expansionist, annexationist Vietnamese aggressors from our units and from Cambodian territory forever ... To exterminate resolutely all CIA agents... to exterminate the enemies of all stripes." ${ }^{33}$ These contemporaneous documents, recording statements of the accused at the time the alleged crimes occurred, provide a valuable insight into whether or not the accused had the requisite criminal intent to commit crimes. Similarly, Khieu Samphan's presence at the CPK Standing Committee meetings demonstrated his active involvement in the making and promoting of CPK policy. ${ }^{34}$

I would like to come back to the importance of the role of independent academics, journalists, analysts and other individuals in the investigation of the crimes committed by the Khmer Rouge in the judicial process at the ECCC. These early inquirers devoted significant parts of their lives to ensure those most responsible were brought to justice at a time when the international community and the Cambodian government were unable to do so. One such person was Alex Hinton who came to the Prosecution's attention in 2006 as a result of a book he published entitled Why Did

\footnotetext{
${ }^{29}$ ECCC, Transcript of Interview with Khieu Samphan, ECCC Case 002 Doc. No. E3/3198, 9.

${ }^{30}$ David Aronowitsch and Staffan Lindberg, dir., Facing Genocide - Khieu Samphan and Pol Pot (2010; Sweden: Story AB), documentary, 41:35-41:40.

${ }^{31}$ Ibid., 43:45-44:00.

${ }^{32}$ Ibid., 44:05-44:25.

${ }^{33}$ FBIS, Phnom Penh Rally Marks $17^{\text {th }}$ April Anniversary, April 16, 1978, ECCC Case 002 Doc. No. E3/562, 9.

${ }^{34}$ CPK Standing Committee Meeting Minutes, 8 March 1976, Attending; Pol Pot, Nuon Chea and Khieu Samphan, ECCC Case 002 Doc. No. E3/231.
} 


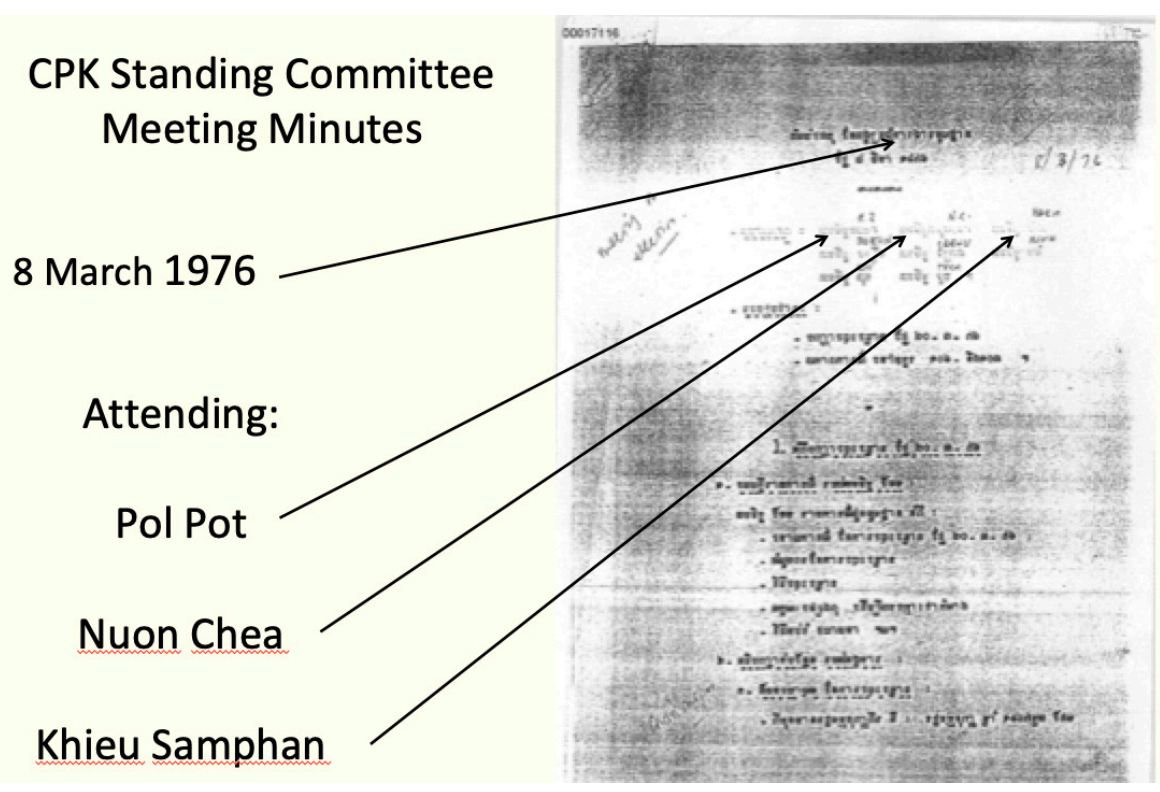

Figure 17. Minutes of CPK Standing Committee meeting on 8 March 1976, indicating that both Nuon Chea and Khieu Samphan attended.

They Kill? ${ }^{35}$ The theme and research of this book addressed the question of why mass killings occurred during the Khmer Rouge period. The book was based on comparative genocide research and a specific study of the alleged genocide and crimes against humanity occurring in Cambodia.

In any criminal case, national and international, it is not required for the prosecution to prove the motivation behind a perpetrator's crime, as opposed to the necessity of proving the intent to commit the crime. Often these two concepts are closely connected but nonetheless they are distinct. However, despite the fact that Alex Hinton's book had highly probative evidence of crimes being committed from first-hand interviews with victims and perpetrators and valuable opinion evidence on how CPK language was used to incite killings constituting genocide and crimes against humanity, among other matters, his book came under close attention for another important reason.

In his book, Alex Hinton sought to identify and understand why individuals at the highest and lowest levels of the CPK and DK structures would persecute and kill Cambodians, and other groups such as the Cham Muslims and Vietnamese. Such information would be valuable for the legacy of the court, so Cambodian society and the international community could learn from this experience.

Consequently, in the second trial against Nuon Chea and Khieu Samphan, in which the genocide and crimes against humanity charges based on mass killings around the country would be heard, the Prosecution requested that Dr. Hinton be called. We wanted the judges and the public to hear an objective analysis of how the mechanics of genocide worked so that the facts in the case could be better understood.

As Alex Hinton testified he demonstrated that his extensive academic career, voluminous publications, and leadership positions held in the area of genocide studies amply enabled him to be classified as an expert on issues such as the cause of the genocide and persecution in Cambodia. As he did in his book, Dr. Hinton gave an articulate and comprehensive account of the societal factors that created conditions for killings on a massive scale and other acts of persecution to occur in Cambodia. He explained to the judges the universal and uniquely Cambodian societal factors that existed both before and during the DK period, which caused the genocide and crimes against

${ }^{35}$ Alex Laban Hinton, Why Did They Kill? Cambodia in the Shadow of Genocide (Berkeley and Los Angeles, University of California Press, 2005). 
humanity to occur. ${ }^{36}$ It was clear in the courtroom that the judges concentrated on every word of his testimony, as he approached the evidence from a macro and micro perspective to explain how these killings took place so systematically.

Dr. Hinton also testified on the information he received first-hand from hundreds of witnesses, who included former Khmer Rouge cadre and survivors who provided evidence of the existence and implementation of the CPK policies to kill specifically Cham Muslims, Vietnamese and other groups. These interviews were conducted in Kampong Cham province in the mid-1990s as part of Alex Hinton's research for his PhD.

A significant part of Dr. Hinton's testimony concerned one aspect of the CPK documents that was being argued as evidence of intent to commit genocide of the Vietnamese. This evidence was identified in the language used by the CPK in their leaders' speeches, publications, and other documentation. For example, in the April 1978 Revolutionary Flag magazine, the CPK acknowledges their "success" in eradicating the Vietnamese from Cambodia, stating "[a]nd now, how about the Yuon? There are no Yuon in Kampuchean territory. Formerly there were nearly 1,000,000 of them. Now there is not one seed of them to be found." ${ }^{\prime 37}$ Alex Hinton testified that language used in this way in CPK documents was done intentionally to incite subordinates to commit genocide against the Vietnamese. ${ }^{38}$

On the last day of Dr. Hinton's questioning, his testimony on this issue caught the close attention of Nuon Chea to such an extent that he requested to be brought up to the courtroom in order to make a statement in response to the expert's opinion. It was very rare that Nuon Chea came into the courtroom, preferring to watch the proceedings in an adjacent room on video due to his health conditions. After a statement by Nuon Chea, in which he said he believed the word 'Youn' was not derogatory towards Vietnamese, Dr. Hinton responded respectfully, "I think that's a valuable pedagogical exercise in general, but in the end I stand strongly by my stance that the word 'Yuon' can be a very incendiary word. It's a word that can incite hatred and violence and in the context of DK it was an incitement to genocide." 39

Sitting at the prosecution bench as this exchange was unfolding, I watched Dr. Hinton ably and respectfully respond to Nuon Chea's view. I thought to myself, would Alex Hinton ever have thought that, when he was that 31-year-old $\mathrm{PhD}$ research student sitting in a village in Kampong Cham province in the middle of Cambodia collecting evidence on the genocide of the Khmer Rouge, that 25 years later he would be discussing his findings with Nuon Chea in a trial where Nuon Chea was charged with genocide on the very facts he was investigating? Being in this position clearly did not intimidate Dr. Hinton. To the contrary, in court he held his resolve to keep his mind trained on the topic and bring to the fore all of the facts to support his opinions under heavy questioning and the opinion of Nuon Chea himself. All Dr. Hinton's prior hard work had paid off, and he was able to make his contribution to the accountability and reconciliation process in Cambodia in one of the most salient ways possible.

The title of this address was Justice for Genocide in Cambodia - The Case for the Prosecution. However, I aimed to steer my remarks to acknowledging the importance of independent academics, journalists, researchers, investigators, analysts and NGOs that take the difficult, dangerous and often thankless course of investigating and analyzing mass human rights abuses when the international community is unable to do so. Without these efforts, important evidence is easily lost, documents are destroyed, opportunities for incisive interviews are gone, witness leads are buried, and the chance to deliver justice decreases by the year. If not for the work of these individuals, independently or together, prior to the establishment of the ECCC, seeking justice for the Khmer Rouge crimes would have been extremely difficult. This activity by these individuals and organizations provides a good lesson to all of us to keep seeking justice for others, even when it feels like nothing will ever be done.

\footnotetext{
${ }^{36}$ ECCC Case 002/02, Trial Transcript, Doc. No. E1/401.1, 14 March 2016, 24, 44-68.

${ }^{37}$ ECCC Case 002/02, Trial Transcript, Doc. No. E1/402.1, 15 March 2016, 49.

${ }^{38}$ ECCC Case 002/02, Trial Transcript, Doc. No. E1/402.1, 15 March 2016, 48-54.

${ }^{39}$ ECCC Case 002/02, Trial Transcript, Doc. No. E1/404.1, 17 March 2016, 83.
} 


\section{Acknowledgements}

This address was prepared with the assistance of Caroline Delava, Martin Hardy and Andreana Paz, legal interns in the Office of the Co-Prosecutor. The opinions in this address are those of the author solely and reflect the concepts and essence of the address delivered at the Conference.

\section{Bibliography}

Aronowitsch, David and Staffan Lindberg, dir. Facing Genocide - Khieu Samphan and Pol Pot. 2010; Sweden: Story AB. Documentary, 94 min.

Becker, Elizabeth. When the War was Over: The Voices of Cambodia's Revolution and Its People. New York: Simon and Schuster, 1998.

Chanda, Nayan. Brother Enemy, The War After the War. New York: MacMillan Publishing Company, 1986.

Chandler, David. Voices from S-21: Terror and History in Pol Pot's Secret Prison. Berkeley and Los Angeles: University of California Press, 1999.

Chon, Gina and Thet Sambath. Behind the Killing Fields, Philadelphia: University of Pennsylvania Press, 2010. https://doi.org/10.9783/9780812201598

Heder, Steve. Cambodian Communism and the Vietnamese Model: Imitation and Independence, 19301975. Bangkok: White Lotus Press, 2004.

Hinton, Alex Laban. Why Did They Kill? Cambodia in the Shadow of Genocide. Berkeley and Los Angeles: University of California Press, 2005.

Kiernan, Ben. The Pol Pot Regime: Race, Power, and Genocide in Cambodia under the Khmer Rouge, 19751979. New Haven and London: Yale University Press, 1996.

Lemkin, Rob, dir. Enemies of the People. 2010; UK and Cambodia: Old Street Films. Documentary, $93 \mathrm{~min}$

Short, Philip. Pol Pot: The History of a Nightmare. New York: Henry Holt \& Company, 2004.

United Nations. Report of the Secretary-General on Khmer Rouge Trials. October 12, 2004. UN Doc. $\mathrm{A} / 59 / 432$. 